\title{
PENGGUNAAN METODE PEMBELAJARAN INVESTIGASI KELOMPOK UNTUK MENINGKATKAN KECAKAPAN SOSIAL SISWA KELAS V SDN AIK AMPAT TAHUN PELAJARAN 2018/2019
}

\author{
Baiq Nursini \\ Sekolah Dasar Negeri Aik Ampat Lombok Tengah
}

\begin{abstract}
Absrak. Tujuan penelitian ini adalah untuk menghasilkan Metode Pembelajaran Investigasi Kelompok yang dapat meningkatkan kecakapan sosial siswa SD. Metode yang digunakan pada penelitian ini adalah metode kuantitatif jenis eksperimen kuasi. Prosedur penelitian yang digunakan yaitu studi pendahuluan, mengembangkan rancangan hipotetik metode, validasi metode, dan evaluasi metode. Populasi penelitian ini merupakan semua siswa kelas V SDN Aik Ampat yang berjumlah 27 orang. Instrumen yang digunakan untuk mengukur efektivitas Metode Pembelajaran Investigasi Kelompok yaitu instrumen kecakapan sosial. Data yang diperoleh dianalisis dengan menggunakan SPSS 16.0 for Windows. Berdasarkan hasil studi pendahuluan profil kecakapan sosial pada siswa kelas V SDN Aik Ampat secara umum masih banyak siswa yang termasuk kriteria kurang cakap. Upaya meningkatkan kecakapan sosial dengan menerapkan rancangan hipotetik Metode Pembelajaran Investigasi Kelompok sebanyak 10 pertemuan, setiap pertemuannya selama tiga jam pelajaran. Hasil penelitian ini menunjukkan bahwa Metode Pembelajaran Investigasi Kelompok terbukti efektif meningkatkan kecakapan sosial siswa kelas V SDN Aik Ampat. Implikasinya bagi pengembangan teori dan praktik psikologi pendidikan di Sekolah Dasar. Rekomendasi penelitian ini ditujukan pada sekolah, guru, dan penelitian berikutnya yaitu tentang Metode Pembelajaran Investigasi Kelompok untuk meningkatkan kecakapan sosial siswa Sekolah Dasar.
\end{abstract}

Kata Kunci : Investigasi Kelompok, konstruktivisme, kooperatif, sosiokultural

\section{PENDAHULUAN}

Peserta didik dalam proses pembelajaran dituntut memiliki kemampuan untuk berinteraksi dengan efektif dan harmonis baik dengan teman, guru, dan masyarakat umum. Kecakapan sosial merupakan kemampuan siswa memahami pikiran dan perasaan individu lain sehingga mampu berinteraksi dengan efektif dan harmonis. Jadi siswa penting memiliki kecakapan sosial yang optimal supaya sukses pada pembelajaran. Salah satu bentuk kesuksesan dalam proses pembelajaran adalah tercapainya semua kompetensi pembelajaran dengan tuntas. Dharma (2008) menyatakan bahwa keberhasilan dalam pembelajaran merupakan belajar tuntas. Belajar tuntas berarti tercapainya semua kompetensi dalam pembelajaran.

Hal-hal yang menyebabkan pentingnya kecakapan sosial untuk kesuksesan pembelajaran, karena beragamnya siswa yang mengikuti proses pembelajaran (dalam Kagan, 2009). Keberagaman siswa pada lingkungan belajar kita tersebut ditunjukkan dengan perbedaan prestasi, adat, budaya, bahasa, lingkungan keluarga, dan ekonomi. Sekarang dan masa yang akan datang keberagaman siswa merupakan sesuatu yang sangat lazim, karena terjadi proses urbanisasi, migrasi, sosial media, pekerjaan orang tua yang beragam, jumlah anggota keluarga, dan lain-lain.

Penelitian pada 10 tahun terakhir pun sudah menyadari pentingnya kecakapan sosial bagi ketuntasan dan kesuksesan siswa. Penyebab lain pentingnya kecakapan sosial, karena adanya kecenderungan mundurnya kecakapan sosial pada setiap individu. Kagan (2009) mengemukakan bahwa beberapa penyebab kemunduran kecakapan sosial yaitu urbanisasi, jumlah anggota keluarga, aktivitas orang tua, sudut pandang pekerjaan setempat, pekerjaan ibu, angka perceraian, ibu tidak pernah menikah kembali, orang tua tunggal, suasana keluarga yang tradisional menghilang, pengaruh negatif media dan teman, kelayakan 
media, tontonan televisi, video game, video dan lirik lagu yang didengar, dan pengaruh teman.

Asumsinya bahwa rendahnya kecakapan sosial akan berimplikasi pada perilaku negatif siswa, serta tidak tercapainya ketuntasan dalam pembelajaran. Secara teoretis perilaku negatif yang ditunjukkan siswa karena kecakapan sosialnya rendah di lingkungan sekitar kita misalnya: berbicara kasar, tidak menghormati guru, orang tua, tidak mampu menghargai pendapat teman, perilaku yang ditunjukkan tidak disukai orang lain, tidak patuh pada aturan, ketika berbuat salah merasa tidak bersalah, kurang peduli dengan orang lain, kikir, mementingkan diri sendiri, tidak bisa menyesuaikan diri dengan lingkungan, dan lain - lain. Albrecht (2009) mengemukakan bahwa penyebab utama rendahnya kecakapan sosial karena kurangnya wawasan sosial. Siswa yang kecakapan sosialnya rendah cenderung tidak mampu mengendalikan diri karena rendahnya rasa empati, penyelerasan, persentasi diri, dan komunikasi.

Hasil studi pendahuluan yang dilakukan pada 27 siswa kelas V SDN Aik Ampat Tahun Pelajaran 2018/2019, bahwa kecakapan sosialnya belum optimal, maka perlu ada upaya peningkatan kecakapan sosial.

Salah satu upaya untuk meningkatkan kecakapan sosial dilakukan dari sudut pandang pendidikan di sekolah. Proses pendidikan di sekolah merupakan salah satu upaya peningkatan kecakapan sosial siswa. Hal ini sesuai dengan pendapat Adler (1997) mengemukakan bahwa peningkatan kecakapan sosial itu perlu dilakukan di luar keluarga. Salah satu lingkungan di luar keluarga yang dapat meningkatkan kecakapan sosial adalah pendidikan di sekolah. Melalui proses pendidikan di sekolah selain dapat meningkatkan pengetahuan juga kecakapan sosial (social intelligence). Salah satu proses pendidikan yang dapat dilakukan melalui proses pembelajaran. Tahapan cara mengajarkan siswa dalam proses pembelajaran ditentukan oleh metode pembelajaran yang dipilih.

Berdasarkan penjelasan di atas maka salah satu upaya untuk meningkatkan kecakapan sosial dalam sudut pandang proses pembelajaran bisa dilakukan melalui merancang metode pembelajaran. Salah satu upaya merancang metode pembalajaran dilakukan, dengan meneliti rancangan hipotetik metode pembelajaran yang mampu meningkatkan kecakapan sosial siswa Sekolah Dasar. Berdasarkan asumsi di atas salah satu rancangan metode pembelajaran yang berlandaskan prinsip belajar demokrasi, interaksi, dan memandang siswa sebagai makhluk sosial adalah Metode Pembelajaran Investigasi Kelompok. Sesuai dengan pandangan Joyce, Weil, dan Calhoun (2009) mengemukakan bahwa fungsi Metode Pembelajaran Investigasi Kelompok untuk mengembangkan kecakapan sosial siswa. Metode Pembelajaran Investigasi Kelompok diharapkan dapat mengintegrasikan seluruh aspek kecakapan sosial dan dapat diterapkan dalam pembelajaran di Sekolah Dasar.

Metode Pembelajaran Investigasi Kelompok merupakan salah satu dari model pembelajaran kooperatif, yang dikembangkan dari pandangan sosiokultural Vygotsky, perkembangan sosial, kecakapan sosial, pembelajaran kooperatif, pembelajaran demokrasi, dan metode Group Investigasidari (Joyce, Weil, dan Calhoun; Kagan; W. Johnson dan T. Johnson; dan Slavin). Michaelis (dalam Joyce, Weil, dan Coulhun, 2009) mengemukakan bahwa inti dari Metode Pembelajaran Investigasi Kelompok adalah membuat sebuah kelompok belajar yang demokratis sehingga dapat mendefinisikan dan mengatasi berbagai masalah sosial. Jadi setelah diterapkan Metode Pembelajaran Investigasi Kelompok pada proses pembelajaran diharapkan mampu meningkatkan kecakapan sosial siswa Sekolah Dasar.

Kecakapan sosial yang hendak ditingkatkan pada penelitian ini terdiri dari dua aspek yaitu kesadaran dan fasilitas sosial. Goleman (2006) menyatakan bahwa ada dua aspek kecakapan sosial yakni kesadaran dan fasilitas sosial. Secara rinci indikator dari aspek kesadaran sosial yang hendak ditingkatkan yaitu : empati dasar, penyelarasan, ketepatan empatik, dan pengertian sosial. Sedangkan indikator dari aspek fasilitas sosial yang hendak dicapai yaitu: sinkroni, presentasi diri, pengaruh, kepedulian. Semua aspek dan indikator kecakapan sosial tersebut perlu dicapai secara menyeluruh karena 
satu kesatuan yang utuh. Kalau semua aspek tersebut dicapai dengan utuh maka kecakapan sosial pada siswa akan meningkat dengan optimal.

Secara umum kecakapan sosial yang perlu ditingkatkan meliputi kemampuan pemahaman terhadap perasaan dan pikiran indvidu lain, serta berinteraksi dengan efektif dan harmonis. Kecakapan sosial merupakan salah satu bagian dari akhlak mulia yang tertera pada UndangUndang Nomor 20 Tahun 2003 tentang Sistem Pendidikan Nasional. Artinya, jika kecakapan sosial siswa meningkat maka berdampak positif pada tujuan pendidikan nasional tentang berakhlak mulia.

Tujuan utama dari penelitian ini untuk menghasilkan metode Pembelajaran Investigasi Kelompok yang dapat meningkatkan kecakapan sosial siswa Sekolah Dasar.

\section{METODE PENELITIAN}

Penelitian ini dilaksanakan pada bulan Agustus-September 2018. Penelitian ini dilaksanakan berdasarkan permasalahan yang terjadi di kelas V SDN Aik Ampat yaitu kecakapan sosialnya belum optimal, maka perlu ada upaya peningkatan kecakapan sosial.

Objek dalam penelitian ini adalah keseluruhan proses dan hasil pembelajaran melalui metode pembelajaran Investigasi Kelompok dengan subjek penelitian ini adalah siswa kelas V SDN Aik Ampat Tahun Pelajaran 2018/2019.

Metode yang digunakan pada penelitian ini yaitu metode eksperimen kuasi dengan rancangan pretest-posttest control group design. Kelompok kontrol dan ekperimen diambil tanpa penempatan acak (without random assignment), dan dilakukan pre test dan post test. Treatment yang diberikan pada kelompok eksperimen dengan menerapkan Metode Pembelajaran Investigasi Kelompok, sedangkan kelompok kontrol dengan metode pembelajaran konvensional.

Tahapan eksperimen pada penelitian ini yaitu:

1) studi pendahuluan variabel terikat,

2) menentukan anggota kelompok eksperimen dan kontrol,

3) memberikan treatment pada kelompok eksperimen,
4) mengukur variabel terikat penelitian (kecakapan sosial), dan

5) membandingkan kondisi kelompok kontrol dan eksperimen dengan tes signifikansi statistik hasil post-test.

Populasi penelitian ini merupakan seluruh siswa kelas V SDN Aik Ampat Kecamatan Jonggat Tahun Pelajaran 2018/2019 sebanyak 27 orang. Sampel studi pendahuluan kecakapan sosial ditentukan tanpa acak pada seluruh siswa kelas V SDN Aik Ampat. Sampel uji coba lapangan metode ditetapkan pada siswa yang termasuk kriteria kurang cakap kecakapan sosialnya yaitu sebanyak 20 orang. Berdasarkan sampel tersebut 10 orang siswa dijadikan kelompok kontrol dan 10 kelompok eksperimen.

Kecakapan sosial yang akan ditingkatkan melalui Metode Pembelajaran Investigasi Kelompok pada kelas eksperimen meliputi dua aspek yaitu kesadaran sosial dan fasilitas sosial. Kedua aspek tersebut terdiri dari delapan indikator yaitu: empati dasar, penyelarasan, keteparan empatik, pengertian sosial, sinkroni, prentasi diri, pengaruh, dan kepedulian. Setiap aspek tersebut dikembangkan menjadi instrumen untuk mengukur kecakapan sosial siswa Sekolah Dasar.

Data yang diperoleh dari instrumen di analisis dengan uji efektivitas, menggunakan desain eksperimen kuasi dalam bentuk pre testpost test control group design. Hipotesis statistik: $\mathrm{H} 0: \mu \mathrm{KE}=\mu \mathrm{KK} \mathrm{H} 1: \mu \mathrm{KE}>\mu \mathrm{KK}$

Uji efektivitas tersebut menggunakan uji signifikansi statistik dengan aplikasiSPSS 16.0 for Windows. Metode Pembelajaran Investigasi Kelompok efektif meningkatkan kecakapan sosial jika $\mathrm{H} 0$ ditolak dan $\mathrm{H} 1$ diterima jika thitung $>$ ttabel atau nilai Sig. $<0,05$.

\section{HASIL DAN PEMBAHASAN}

\section{Hasil Penelitian}

Hasil penelitian ini dideskripsikan yaitu:

\section{Profil Kecakapan sosial siswa kelas V Sekolah Dasar}

Profil umum kecakapan sosial siswa kelas V SDN Aik Ampat Tahun Pelajaran 2018/2019, berdasarkan hasil studi pendahuluan masih banyak yang termasuk kriteria kurang cakap, secara rinci sebagai berikut: 
a) Kecakapan sosial siswa kelas V SDN Aik Ampat yang termasuk kategori cakap sebanyak 8 orang atau 29,6\%;

b) Kecakapan sosial siswa kelas V SDN Aik Ampat yang termasuk kategori cukup cakap sebanyak 5 orang $18,5 \%$;

c) Kecakapan sosial siswa kelas V SDN Aik Ampat yang termasuk kategori kurang cakap sebanyak 14 orang atau 51,9\%.

2. Proses Penerapan Metode Pembelajaran Investigasi Kelompok untuk Meningkatkan Kecakapan Sosial

Metode Pembelajaran Investigasi Kelompok hasil penelitian ini melalui tahapan sebagai berikut ini : 1) kajian teoretis dan empirik kecakapan sosial siswa Sekolah Dasar dan pembelajaran investigasi kelompok, 2) menyusun rancangan hipotetik Metode Pembelajaran Investigasi Kelompok, 3) analisis kelayakan rancangan hipotetik Metode Pembelajaran Investigasi Kelompok, dengan teknik validasi, keterbacaan, dan keperaktisan oleh pakar dan praktisi pendidikan, 4) uji coba lapangan rancangan hipotetik Metode Pembelajaran Investigasi Kelompok dengan teknik eksperimen kuasi, 5) uji efektivitas rancangan hipotetik Metode Pembelajaran Investigasi Kelompok terhadap peningkatan kecakapan sosial menggunakan uji signifikansi statistik dengan menggunakan aplikasi SPSS 16.0 for Windows, 6) evaluasi rancangan hipotetik Metode Pembelajaran Investigasi Kelompok berdasarkan hasil uji signifikansi statistik, 7) penetapkan rancangan hipotetik menjadi Metode Pembelajaran Investigasi Kelompok untuk meningkatkan kecakapan sosial siswa Sekolah Dasar. Metode Pembelajaran Investigasi Kelompok diterapkan (sebagai treatment) pada kelas eksperimen. Penerapan Metode Pembelajaran Investigasi Kelompok pada kelas eksperimen sebanyak 10 pertemuan setiap pertemuannya selama tiga jam pelajaran. Penetapan jumlah pertemuan tersebut mangacu hasil penelitian Shlomo \& Shechar (1988) sedangkan waktu pertemuannya berdasarkan Peraturan Menteri Pendidikan Nasional Nomor 22 Tahun 2006 tentang Standar Isi. Sedangkan pada kelas kontrol diterapkan metode pembelajaran konvensional. Jumlah pertemuan pada kelas kontrol sama dengan kelas eksperimen, yaitu pada hari dan materi yang sama, namun waktunya yang berbeda. Penerapan Metode Pembelajaran Investigasi Kelompok pada penelitian ini diterapkan pada mata pelajaran IPA, dengan Kompetensi Dasar: mendeskripsikan sifat-sifat cahaya.

Setiap tahapan rancangan hipotetik Metode Pembelajaran Investigasi Kelompok yang dilaksanakan terdiri dari satu pertemuan ada juga yang dua pertemuan, secara rinci sebagai berikut: (a) Tahapan 1 investigasi topik, dilaksanakan dua pertemuan selama enam jam pelajaran (6x35 menit); (b) Tahapan 2 pengelompokan siswa, dilaksanakan sebanyak satu pertemuan selama tiga jam pelajaran (3x35 menit); (c) Tahap 3 pembagian tugas, dilaksanakan satu pertemuan selama tiga jam pelajaran (3x35 menit); (d) Tahap 4 investigasi dan diskusi, dilaksanakan dua pertemuan selama enam jam pelajaran (6x35 menit); (e) Tahap 5 menyusun laporan hasil investigasi, dilaksanakan dua pertemuan selama enam jam pelajaran (6x35 menit); (f) Tahap 6 pelaporan hasil investigasi, dilaksanakan satu pertemuan selama tiga jam pelajaran ( $3 \times 35$ menit); dan $(\mathrm{g})$ Tahap 7 evaluasi hasil investigasi, dilaksanakan satu pertemuan selama tiga jam pelajaran $(3 \times 35$ menit).

\section{Gambaran Efektivitas Metode Pembelajaran Investigasi Kelompok Meningkatkan Kecakapan Sosial Siswa Sekolah Dasar}

Uji efektivitas Metode Pembelajaran Investigasi Kelompok untuk meningkatkan kecakapan sosial siswa Sekolah Dasar dengan menggunakan data pre test dan post test pada kelompok kontrol dan eksperimen. Sebelum melakukan uji efektivitas metode pembelajaran investigasi kelompok, terlebih dahulu dilakukan uji asumsi statistik yaitu uji normalitas dan homogenitas. Uji statistik normalitas dengan teknik Kolmogorov-Somornov dengan nilai signifikansi probabilitasnya adalah $\alpha=0,05$ yaitu kelas eksperimen 0,147>0,05 dan kelas kontrol 0,049>0,05. Hasil uji homogenitas pada data pre test dan post test dengan meggunakan SPSS 16.0 for Windows yaitu memiliki nilai $\mathrm{p}$ (sig) $>0,05$ yaitu $0,067>0,05$.

Hasil uji efektivitas data pre test dengan teknikuji t (independen simple t- test data pre 
test) kelompok eksperimen dan kontrol yaitu tidak signifikan. Hal tersebut ditunjukkan dengan nilai $\mathrm{P}(\mathrm{Sig})>0,05$ yaitu $0,325>0,05$, artinya baik kelas eksperimen maupun kontrol sebelum menerima perlakuan pada kondisi yang sama yaitu kriteria kurang cakap kecakapan sosialnya.

Hasil uji efektivitas data posttes dengan teknik uji $\mathrm{t}$ (independen simple t-test data pretes) kelompok eksperimen terbukti signifikan, yaitu nilai $\mathrm{P}(\mathrm{Sig})<0.05$, artinya setelah menerapkan Metode Pembelajaran Investigasi Kelompok terjadi peningkatan kecakapan sosial yang signifikan pada kelas eksperimen.

Hasil uji efektivitas Metode Pembelajaran Investigasi Kelompok terbukti efektif meningkatkan hampir semua indikator kecakapan sosial, kecuali pengertian sosial. Jadi secara umum Metode Pembelajaran Investigasi Kelompok terbukti efektif meningkatkan kecakapan sosial siswa Sekolah Dasar.

\section{PEMBAHASAN}

Profil kecakapan sosial siswa kelas V SDN Aik Ampat sebelum menerapkan Metode Pembelajaran Investigasi Kelompok secara umum masih banyak yang termasuk kriteria kurang cakap kecakapan sosialnya. Secara teoretis seharusnya siswa kelas $\mathrm{V}$ sudah memiliki kecakapan sosial yang optimal. Siswa kelas V Sekolah Dasar berada pada rentang usia 10-11 tahun yang secara tugas perkembangan sudah harus memiliki kemampuan berkomunikasi, sikap peduli, empati, dan bekerja sama (Papalia, 2014). Hurlock (1978) menyebutnya tugas perkembangan sosial pada masa anak-anak akhir (6-12 tahun) terdiri dari dua yaitu sikap sosial dan tidak sosial. Sikap sosial tersebut merupakan aspek-aspek yang terdapat pada kecakapan sosial. Jadi setiap siswa dapat menunjukkan perilaku sosial dan kurang menunjukkan perilaku tidak sosial dalam perkembangannya, apabila memiliki kecakapan sosial yang optimal.

Kecakapan sosial siswa penting ditingkatkan karena menentukan kesuksesan hidupnya. Werham dan Carnegie (dalam Suyono, 2007) menyatakan bahwa kecakapan sosial pada diri seseorang berpotensi untuk meraih sukses. Ruang lingkup kesuksesan yang dimaksud tidak terbatas yaitu mencakup semua aspek kehidupan yaitu aspek fisik dan psikis. Sedangkan kalau ditinjau diri teori sosiokultural Vygotsky (dalam Schunk, 2012) bahwa kunci perkembangan manusia menitik beratkan pada faktor interpersonal,intrapersonal, dan kultural historis, selain itu konteks perkembangan dan pembelajaran tidak bisa dipisahkan. Terkait dengan itu kecakapan sosial mendukung terhadap perkembangan dan pembelajaran siswa atau pun sebaliknya.

Salah satu upaya meningkatkan kecakapan sosial pada siswa Sekolah Dasar dengan merancang Metode Pembelajaran Investigasi Kelompok. Metode Pembelajaran Investigasi Kelompok dikembangkan berdasarkan prinsip belajar kooperatif yang berlandaskan teori belajar kontrukvisme sosiokultural Vygotsky. Metode Pembelajaran Investigasi Kelompok dirancang berlandasakan strategi dan model investigasi kolompok (group investigation) Shlomo \& Shechar (1988); Slavin (2005); W. Johnson dan T. Johnson (2008); Joyce, Weil, dan Calhoun (2009), dan Kagan (2009).

Tahapan Metode Pembelajaran Investigasi Kelompok yang dirancang pada penelitian ini yaitu: 1) investigasi topik, 2) pengelompokkan siswa, 3) pembagian tugas, 4) investigasi dan diskusi, 5) menyusun laporan hasil investigasi, 6) pelaporan hasil investigasi, 7) evaluasi hasil investigasi. Tahapan tersebut dilaksanakan pada siswa kelas $\mathrm{V}$ yang jadi kelas eksperimen sebanyak 10 pertemuan, setiap pertemuannya tiga jam pelajaran.

Hasil uji efektivitas menunjukkan bahwa, setelah penerapan metode pembelajaran investigasi kelompok pada kelompok eksperimen terbukti efektif meningkatkan kecakapan sosial siswa Sekolah Dasar. Peningkatan kecakapan sosial pada kelas eksperimen meliputi aspek kesadaran dan fasilitas sosial dengan indikator empati dasar, penyelarasan, ketepatan empatik, sinkroni, persentasi diri, pengaruh, dan kepedulian. Jadi keadaan empirik pada kelas eksperimen sudah menunjukkan pada individu yang cakap sosialnya.

Hasil penelitian ini ada satu indikator yang tidak meningkat dengan signifikan yaitu 
pengertian sosial. berdasarkan kajian teoretis penyebabnya yaitu: penerapan metode pembelajaran investigasi kelompok pada penelitian ini tidak secara khusus mempelajari tentang realitas sosial melainkan materi pelajaran, jumlah siswa pada kelas eksperimen sangat sedikit, dan tidak terlibat langsung dengan masyarakat yang luas.

Kondisi tersebut kurang mendukung proses pembelajaran kognisi sosial, yang melingkupi pembelajaran langsung atau observasional, sehingga prinsip kausalitas timbal balik kognisi sosial Bandura kurang berjalan dengan optimal. Bandura (dalam Schunk, 2012) mengemukakan bahwa asumsi dari pembelajaran berdasarkan teori kognisi sosial perlu adanya interaksi timbal balik antara manusia, perilaku, dan lingkungan, hal tersebut dapat dilakukan melalui praktik atau pengamatan. Terkait dengan itu agar kognisi sosial siswa meningkat perlu terlibat langsung pada realitas sosial yang sebenarnya atau melalui pengamatan.

Jumlah siswa kelas eksperimen yang sangat sedikit berakibat kurang terbangunnya proses interaksi sosial yang kompleks pada siswa. Melalui interaksi sosial yang kompleks akan semakin banyak kemungkinan terjadinya modeling. Bandura (dalam Schunk, 2012) mengemukakan bahwa ada tidaknya fungsi pemodelan yaitu pemfasilitasan respon, penghilang hambatan, dan pembelajaran observasional. Secara umum penyebabnya karena tidak mempelajari masalah sosial secara khusus dan belum terjadinya interaksi sosial yang kompleks.

\section{KESIMPULAN}

Berdasarkan hasil penelitian tindakan kelas yang telah dilaksanakan, maka penulis menyimpulkan sebagai berikut:

a. Hasil studi pendahuluan menunjukkan, bahwa secara umum profil kecakapan sosial siswa kelas V SDN Aik Ampat Tahun Pelajaran 2018/2019 masih banyak siswa yang termasuk kriteria kurang cakap.

b. Proses penerapan Metode Pembelajaran Investigasi Kelompok untuk meningkatkan kecakapan sosial sebanyak tujuh tahapan yang dilakukan dalam 10 pertemuan, setiap pertemunnya selama tiga jam pelajaran.
Secara rinci tahapan Metode Pembelajaran Investigasi Kelompok sebagai berikut ini: 1) tahap investigasi topik; 2) pengelompokan siswa; 3) pembagian tugas; 4) investigasi dan diskusi; 5) penyusunan laporan hasil investigasi; 6) pelaporan hasil investigasi; 7) evaluasi hasil investigasi.

c. Metode Pembelajaran Investigasi Kelompok terbukti efektif meningkatkan hampir semua indikator kecakapan sosial siswa Sekolah Dasar; kecuali indikator pengertian sosial.

\section{DAFTAR PUSTAKA}

Adler, Alfred. (1997). Under Standing Life. USA, England: Oneworld Publications \& Oxford.

Albrecht, Karl. (2006). Social Intelligence, The New Science of Success. San Francisco. Jossey-Bass.

Apriyadi, Debi., Supardi., \& Sarengat. (2015). Penerapan Model Group Investigation Untuk Meningkatkan Hasil Belajar Siswa Sekolah Dasar. Jurnal: Fakultas Keguruan Dan Ilmu Pendidikan Universitas Lampung.

Dharma, Surya. (2008). Kriteria dan Indikator Keberhasilan Pembelajaran. Jakarta: Direktur Tenaga Kependidikan \& Ditjen PMPTK.

Ganaie, M.Y., \& Mudasir, Hafiz. (2015). A Study of Social Intelligence \& Academic Achievement of College Students of District Srinagar, J\&K, India. Jurnal: Journal of American Science.

Hurlock, Elizabeth. (1978). Perkemban Anak Jilid 1 (Penerjemah: Meitasari Tjandrasa dan Muslichah Zarkasih). Jakarta: Erlangga.

Joyce, Bruce., Weil, Marsha., \& Calhoun, Emily. (2009). Models of Teaching, (Penerjemah: Achmad F \& Ateilla M). Yogyakarta: Pustaka Pelajar.

Kagan, Spencer. \& Kagan, Miguel. (2009). Kagan Cooperative Learning. San Clemate: Kagan Publishing.

Papalia, Diane E. \& Feldman, Ruth Duskin. (2014). Menyelami Perkembangan Manusia Buku 2. Jakarta: Salemba Humanika. 
Peraturan Menteri Pendidikan Nasional Nomor 22 Tahun 2006 tentang Standar Isi.

Schunk, Dale H. (2012). Learning Teories, (Penerjemah: Eva Hamidah dan Rahmat Fajar). Yogyakarta: Pustaka Pelajar.

Shlomo, Sharan.,\& Shachar, Hana. (1988). Language and Learning in the Cooperative Classroom. New York: Springer Verlag.

Slavin, Robert E. (2005). Cooperative Learning, (Penerjemah: Narulita Yusron). Bandung: Nusa Media.

Suyono, Hadi.(2007). Social Intelligence. Jogjakarta: Ar- Ruzz Media.

Undang-Undang RI No. 20 Tahun 2003 tentang Sistem Pendidikan Nasional. 